\section{Seed Germination of Magnolia dealbata Zucc. (Magnoliaceae), An Endangered Species from Mexico}

\author{
Andrew P. Vovides ${ }^{1}$ and Carlos G. Iglesias ${ }^{2}$ \\ Jardín Botánico Francisco Javier Clavijero, Instituto de Ecología, A.C., Apdo \\ Postal 63, Xalapa, Veracruz, 91000 Mexico
}

Additional index words. seed germination, warm-water treatment, cloud-forest species, threatened species

Magnolia dealbata Zucc. (eloxóchitl) is a little known species, thought extinct until 1977 when the species was rediscovered. According to Treseder (1978), M. dealbata has not been cultivated, and prior attempts to cultivate this species from seed at the Jardín Botánico Clavijero(JBC) have been unsuccessful. Magnolia dealbata is an endangered species that grows in cloud-forests, which are themselves endangered ecosystems, at elevations between 1400 and $2000 \mathrm{~m}$; in most cases populations consist of just a few trees. This species merits rescue and propagation for future ecological restoration projects in cloud-forests, for ornamental landscaping, and for pharmacological research, since $M$. dealbata is used as a local medicine where the flowers and bark are collected for preparation of a heart remedy. Magnolia dealbata is related to $M$. macrophylla Michx. (big leaf magnolia) and to $M$. ashei Weath. in the section Rhytidospermum (Vázquez, 1990).

Received for publication 21 Dec. 1995. Accepted for publication 21 Mar. 1996. We thank Eduardo Cervantes for technical assistance and Sr. Alejo of Coyopola, Veracruz, for allowing seed collection. This project was financed in part by the Consejo Nacional de Ciencia y Tecnología (CONACyT) project no. 0063-N9106 and Fauna and Flora Preservation Society project no. 92/6/2. The cost of publishing this paper was defrayed in part by the payment of page charges. Under postal regulations, this paper therefore must be hereby marked advertisement solely to indicate this fact.

${ }^{1}$ Curator of living collections.

${ }^{2}$ Technician.
Ripe seed of $M$. dealbata were collected during Sept. and Oct. 1992. Seed from as many trees as possible from the largest population known $(\approx 100$ trees) were collected to ensure a reasonable sampling of genetic diversity. All seed was mixed and sampled randomly for the experiment. Propagation techniques for ornamental magnolias reported by Dirr and Heuser (1987) were followed with some modification. A warm-water soak of $40^{\circ} \mathrm{C}$ for $24 \mathrm{~h}$ was used to overcome inhibition of germination caused by seed coverings (Martin Staniforth, pers. comm.).

Seeds for stratification were cleaned by removing the exocarp and surface-sterilizing with $10 \%$ n-alkyl $\left(60 \% \mathrm{C}_{14}, 30 \% \mathrm{C}_{16}, 5 \% \mathrm{C}_{12}\right.$, $5 \% \mathrm{C}_{18}$ ) dimethyl benzyl ammonium chloride and $10 \%$ n-alkyl $\left(68 \% \mathrm{C}_{12}, 32 \% \mathrm{C}_{14}\right)$ dimethyl ethylbenzyl ammonium chloride (Physan-20; Maril Products, Tustin, Calif.). They were stored in damp sterile sand in closed sterilized

Table 1. Percent germination of Magnolia dealbata (controls 0 months) and after stratification at 5 ${ }^{\circ} \mathrm{C}$ for various periods, with and without warmwater treatment $\left(40{ }^{\circ} \mathrm{C}\right.$ for $\left.24 \mathrm{~h}\right)$.

\begin{tabular}{lcr}
\hline \hline & \multicolumn{2}{c}{ Germination (\%) $\pm \mathrm{SE}$} \\
\cline { 2 - 3 } $\begin{array}{l}\text { Stratification } \\
\text { period (months) }\end{array}$ & $\begin{array}{c}\text { Warm water- } \\
\text { treated }\end{array}$ & Not treated \\
\hline 0 & $40 \pm 2.5$ & $25 \pm 2.5$ \\
6 & $39 \pm 1.1$ & $35 \pm 3.2$ \\
7 & $29 \pm 6.5$ & $28 \pm 6.0$ \\
8 & $19 \pm 3.4$ & $28 \pm 4.2$ \\
9 & $31 \pm 3.0$ & $29 \pm 2.0$ \\
10 & $22 \pm 2.5$ & $35 \pm 1.0$ \\
\hline
\end{tabular}

glass containers to prevent water loss, and kept at $5{ }^{\circ} \mathrm{C}$.

Germination trials were conducted on seeds using the following treatments: one lot only of freshly collected and cleaned seed stratified at $0{ }^{\circ} \mathrm{C}$ for 10 days, then sown immediately; the rest of the seed were stratified at $5^{\circ} \mathrm{C}$ for 0,6 , $7,8,9$, and 10 months and sown immediately after these periods. For each trial, half of the seeds (three replications of 200 seeds each) were subjected to a further treatment of immersing in water at $40{ }^{\circ} \mathrm{C}$ for $24 \mathrm{~h}$ before sowing. The other half was directly sown into pasteurized vermiculite after each respective cold storage period. An unheated greenhouse $\left(13-32{ }^{\circ} \mathrm{C}\right)$ was used for the experiment and seed was considered germinated as soon as the radicle had emerged.

The highest percent germination was obtained from the nonstratified (control) seeds sown after warm-water treatment (Table 1). The better germination of the warm watertreated seed than of the control was probably due to the removal of chemical germination inhibitors still adhering to the seedcoat after removal of the fleshy aril. Dirr and Heuser (1987) reported that the fleshy arils of Magnoliaceae contain inhibitors that delay germination. There was a general reduction in germination of warm water-treated seeds for storage periods longer than 6 months. Stratification of freshly collected seed at $0{ }^{\circ} \mathrm{C}$ for 10 days resulted in only $14 \%$ and $13 \%$ germination of seed treated with and without warm water, respectively. This low germination percentage may have been caused by cold injury.

Combining growth regulators with hotwater treatment of freshly collected and coldstored seeds in an attempt to improve germination percentage needs to be investigated to assure the long-term survival of this endangered species through reintroduction.

\section{Literature Cited}

Dirr, A. and C.W. Heuser, Jr. 1987. Reference manual of woody plant propagation. Varsity Press, New York. p.149-153.

Treseder, N. 1978. Magnolias. Western Printing Serv., Bristol, U.K.

Vázquez, J.A. 1990. Taxonomy of the genus Magnolia (Magnoliaceae) in Mexico and Central America. MS Thesis (Botany), Univ. of Wisconsin, Madison. 